\title{
Assessment of Availability, Adequacy and Utilization of Instructional Resources for Teaching Public Secondary School Students in Delta State Nigeria
}

\author{
Dr Adams Omokaro Ekwevugbe ${ }^{1^{*}} \quad$ Folashade Oludolapo Atare ${ }^{2}$ \\ 1 Department of Educational Foundations, Delta State College of Education, Mosogar \\ 2 Department of Curriculum \& Instructions, Delta State College of Education, Mosogar
}

\begin{abstract}
The research is financed by Tertiary Education Trust Fund (TETFund)
Abstract

The purpose of the study was to assess availability, adequacy and utilization of instructional resources for teaching secondary school students in Delta State. The study examined the availability of instructional resources in the state. It also examined adequacy and extent of utilization of resources in public secondary schools in the state. The System Resource Theory of organizational effectiveness provided the theoretical base for the study. The study adopted the ex-post-facto research design. The population of the study included all public secondary schools in Delta State out of which 100 public secondary schools was selected using the stratified random sampling technique. Data was collected with the aid of a checklist adapted from West African Examination Council (WAEC) guidelines for re-inspection and recognition of schools and subjects and a questionnaire to be designed for the study. The following findings were made including the fact that instructional resources for teaching are available in $64.16 \%$ of secondary schools in Delta State. Instructional resources are $40.66 \%$ adequate in secondary schools in the state. Instructional resources for teaching students in secondary schools in the state are fully utilized. Recommendations were made to cushion the impact on the state's educational system ; the government should strive to ensure adequacy of instructional resources in the schools by making available more resources to enhance sufficiency; The extent of physical resources adequacy should be improved upon to make the classrooms, staff rooms and general school environment conducive for learning and principals and their vice should be adequately trained on effective utilization of limited instructional resources to enhance the attainment of school goals and objectives.
\end{abstract}

Keywords: Assessment of Availability, adequacy and Utilization, Instructional Resources for Teaching, Public Secondary Schools.

DOI: $10.7176 / \mathrm{JEP} / 13-3-08$

Publication date: January $31^{\text {st }} 2022$

\section{Introduction}

It is obvious that Nigeria desires and clamours for technological advancement. It is translated into reality only if there are conscious efforts to prepare our students adequately to face the prevalent under-achievement in schools. Rather than the adoption of theoretical education of teaching subjects such as chemistry, physics, biology , mathematics and other subjects, students should be taught with the necessary instructional resources that will make teaching and learning to achieve the desired goals and objectives (Dawari, 2012).

It is well known among educators that the educational experience involving the learner actively participating using concrete examples are retained longer than abstract experiences. Concrete experience facilitates learning and the acquisition, retention and usability of abstract symbols. We need an educational system that is practical in outlook and scientific in orientation for development. However, only educational institutions stocked with instructional resources that are well utilized by skilled teachers can provide this all important transformation.

The foundation of all learning in Science and Technology is first-hand experience with real things in form of equipment. Therefore, if Science Education is to be learnt effectively, it must be experienced. Unfortunately, instructional materials are scarce, expensive and not adequate in secondary schools. The place of well-equipped laboratory and workshop cannot be over emphasized. There is no known method by which science and technical knowledge can be transferred to students without equipment and practical laboratory work.

Adequacy of instructional resources ensures smooth operation of a school and enhances effective teaching and learning activity and when this is so, there is likely to be a higher level of educational attainment by students. The adequacy of materials in form of print, visual, audio, audio-visual, projected, non-projected as well as graphic materials are a vital pre-requisite for the operation of secondary education because they facilitate the teaching and learning processes in the school and are needed to generate manipulative skills in pupils.

Instructional resources in teaching and learning makes students to learn more and retain better what they have been taught, it also promotes and sustain students' interest. These according to stakeholders are not adequate in the schools. They are acutely in short supply at all levels. For instance, laboratory, workshop and other teaching aids are perceived by stakeholders as inadequate, while chemicals, tools, books and other supplies are terribly inadequate. Indeed, print and graphic materials, films, cassettes, radios, television sets, computers, textbooks and 
maps are a rarity even though they are the ingredients for promoting quality education in any country. Secondary schools with adequate resources materials would stand a better chance of having better results than poorly equipped ones. (Igbinoghene \& Edokpolor ,2014).

The utilization of resources in the teaching process brings about fruitful learning because it stimulates students' senses as well as motivates them. Goal attainment in any school depends on supply and utilization of educational resources which enhances proper teaching and learning, variation in resources distribution may lead to inequality both in learning and in achievement. The available material resources have to be properly and adequately utilized and taken care of from time to time because students learn more when they are actively involved in utilization of resources. Instructional resources availability, adequacy and level of utilization are one of the most dependable parameter for the measurement of the operational success of secondary schools.

Studies have revealed that laboratories and science materials, maps and globes, libraries, and other expensive components are needed if the higher-level concepts and thinking skills inherent in curriculum at this level are to be taught (Hawthorne cited in Babalola \& Ayeni, 2009). The present high class sizes must be relatively reduced since laboratory workspaces are limited and students in all subjects need opportunities to interact with teachers.

Igbinoghene and Nosahaba (2014) defined instructional resources as the sum total of the input that goes into the education system. Instructional resources refer to people, materials and facilities that can be used to encourage, promote and facilitate teaching and learning activities. They are things needed for instructions and acquisition of education. They are factors, which are turned to, for assistance if success is the desired goals of the individual or organization. They can help the teacher to teach more effectively and efficiently and the learner to learn faster and better. The quality and combination of resources needed depend on both the number of students to be served and the nature of the process and the organizational objectives.

The school resources when adequately provided and effectively utilized could lead to students' proper developments in schools is classified into two main areas: human resources and material resources. The human and material resources for education are many and diverse. The most abundant of the resources however are the human beings who engage in the education enterprise as teachers, leaders, administrators and supervisors and those who help to support the schools like the community leaders, parents and members of Parents Teachers Association.

According to Umezulike (2015), many schools lack the essential infrastructure for them to function properly and effectively, resources for whatever activity in education are in short supply. The majority of schools whether urban or rural has no potable water, lack proper sanitation and has no electricity supply. The physical states of the classrooms are very poor with floors full of holes, broken roofs and ceiling. Windows and doors are not lockable where they exist. Adeyanju and Oyetubo (2012) opined that despite her enormous natural and human resources, Nigeria's education system is bedeviled with the challenges of underfunding and thus poor infrastructure, inadequate classroom and teaching aids (projectors, computer, libraries and laboratories) paucity of quality teachers and poor or polluted learning environment. School system is further plagued with numerous social vices like examination malpractices and cultism (Edokpolo, 2011)

Asiyai (2012) wrote that facilities in public secondary schools in Delta state were in a state of disrepair and further stated that school facilities depreciation were encouraged by excess pressure on available facilities. The problem above is very disturbing as some of the existing buildings from observation suffer different degree of dilapidation. Durosaro (2010) explained that there is a widespread shortage of classrooms, shortage of both pupils' and teachers' furniture.

Oluwuo and Ekuro (2014) investigated physical resources for the implementation of Universal Basic Education (UBE) in Rivers state and concluded that physical resources abound but is grossly inadequate especially in the rural primary schools. The provision of desired facilities is highly politicized to the detriment of schools in the rural areas. There is a great disparity between rural and urban schools in terms of provision of physical resources. There is, according to the authors, no clear-cut optimal utilization of available resources as cases of over utilization was glaring in the rural schools.

The scarcity or non-availability of these educational resources will constrain educational system from attainment of educational goals and objectives. According to Olelewe; Nzeadibe and Nzeadibe (2014) availability of educational resources such as material and human capacity makes a school environment conducive to teaching and learning. The extent to which an educational institution attains her objectives is directly proportional to the educational resources available and their level of utilization.

Akinsanya (2010) commenting on educational resources says they are important because the goal of any school depends on adequate supply and utilization of physical and material resources among others as they enhance proper teaching and learning the reason why this study is important. There is no known method by which science and technical knowledge can be transferred to students without equipment and practical laboratory work. Instructional resources in teaching and learning makes students to learn more and retain better what they have been taught, it also promotes and sustain students' interest. These according to Ugwanyi (2013) are not adequate in the schools. 
Asiyai (2012) carried out a study to investigate school facilities in public secondary schools in Delta State. The findings of the study revealed that facilities in the schools are generally in a state of disrepair. The findings further revealed that maintenance carried out on school facilities were inadequate for majority of the facilities. The simple analogy is that of a country pursuing quality education in a vacuum. The author recommended that provision should be made towards procurement of training materials to enhance skill training, as well as that government should budget for facilities maintenance.

The extent of resources utilization in Nigerian schools today is being called to question both within and outside the profession. It has been generally agreed that the school resources are poorly utilized simply because the school lacks qualified personnel and manpower resources needed for the improvement of instruction. For resources to be properly utilized there is the need to employ dynamic school heads that are professional grown. Adeoye and Popoola (2011) stated that for learning to take place, learners must have access to necessary information materials and resources. They have to interact with tangible and intangible resources to ensure some level of performance, on this Ekwutosi and Ogbonnaya (2015) believes that urban and rural schools receive equal resources and are equally defective in terms of educational resources.

\section{Statement of the Problem}

The secondary schools in Delta State are battling with one crisis or the other, ranging from inadequate staff, inadequate and poor condition of instructional resources that makes teaching and learning to be meaningful. The availability, adequacy and level of utilization of resources could be a major determinant for the quality of output from the schools. Existing information on the level of achievement of students in Senior Schools Certificate Examination is quite disturbing. Researchers have adduced this poor achievement of students to inadequate and poor funding of education and inadequate material resources.

The situation of instructional resources in the secondary schools has been reported by stakeholders as being inadequate and unfriendly to effective teaching and learning due to the deplorable condition of the educational resources. The public secondary schools across Delta State have also been linked with very low level of utilization of instructional resources as well as poor distribution of these resources across the geographical spread of the state.

Government however claims that several millions of Naira has been invested in the provision of instructional resources in recent years leading to an expected boost in the availability and adequacy of this all important resources. The said resources are expected to have been distributed across all secondary schools in the state, it is the hope of government that these will ease the scarcity and improve teachers' ability to appropriately translate the curriculum into students' clear understanding and educational attainment if properly utilized.

The problem of this study therefore, is to assess instructional resource availability, adequacy and utilization in secondary schools in Delta State. Specifically, are instructional resources available, adequate and utilized in secondary schools in Delta State?

\section{Purpose of the Study}

The purpose of this study is to assess instructional resource availability, adequacy and utilization in secondary schools in Delta State. The specific objectives of the study are to:

1 Determine instructional resources availability for teaching in secondary schools in Delta State.

2 Ascertain instructional resources adequacy for teaching in secondary schools in Delta State.

3 Ascertain instructional resources utilization for teaching in secondary schools in Delta State.

\section{Research Questions}

The following research questions were raised to guide the study.

1 Are instructional resources available for teaching in secondary schools in Delta State?

2 Are instructional resources adequate for teaching in secondary schools in Delta State?

3 What is the level of utilization of instructional resources for teaching in secondary schools in Delta State?

\section{Methodology}

The study adopted the ex-post facto research design. Ex-post facto research design is a systematic empirical inquiry in which the researcher does not have direct control of the variables because their manifestations have already occurred.

The population of the study consists of four hundred and forty five (445) public secondary schools in Delta States of Nigeria as at the 2019/2020 academic year.

A sample of one hundred (100) public secondary schools representing $22 \%$ was used. The researchers used the stratified sampling technique to select the secondary schools from twenty five (25) local government areas of Delta State. Stratified sampling technique was used in selecting schools on the basis of rural and urban areas. This categorization will help to determine whether there were variations in availability, adequacy and utilization of instructional resources in the state. 
There were two instruments for the study. The first is a checklist adapted from West African Examination Council (1999) guidelines for re-inspection/recognition of schools and subjects. The second is a questionnaire titled Questionnaire on Utilization of Instructional Resource to Teach in Secondary Schools in Delta State (QUIRTSS) which will be sub - divided into two parts (section A and B) Section A will require data regarding the name and geographical location of the school. Section B will focus on items relating to the research questions. The respondents will be requested to describe the extent of utilization of the items presented using the following parameters: least utilized (LU), underutilized (UU), moderately utilized (MU), fully utilized (FU). The questionnaire was validated by experts in the Faculty of Education, University of Benin. The test-retest reliability test in public secondary schools in Edo State involving 30 randomly selected secondary schools will be used to determine the reliability of the instrument at 0.05 level of significance using Pearson's product correlation coefficient.

The checklist and questionnaire was administered by the researchers with the help of twenty five (25) trained research assistants to the sampled secondary schools. The data collected was analyzed using frequencies, percentages, mean, standard deviation and t-test statistics.

\section{Presentation of Results}

\section{Research Question 1}

Are instructional resources available for teaching in secondary schools in Delta State?

Table 2 Availability of Instructional Resource materials

\begin{tabular}{|c|c|c|c|c|c|c|}
\hline $\mathbf{S} / \mathbf{N}$ & Material Resources & $\begin{array}{c}\text { Yes } \\
\text { (Available) }\end{array}$ & $\%$ & $\begin{array}{c}\text { No } \\
\text { (Not Available) }\end{array}$ & $\%$ & Remarks \\
\hline 1. & Chalkboard & 81 & $81 . .00$ & 19 & 19.00 & Available \\
\hline 2. & Marker Board & 49 & 49.00 & 51 & 51.00 & Not available \\
\hline 3. & Textbooks & 83 & 83.00 & 17 & 17.00 & Available \\
\hline 4. & Realia & 32 & 32.00 & 68 & 68.00 & Not available \\
\hline 5. & Tape recorder & 7 & 7.00 & 93 & 93.00 & Not available \\
\hline 6. & Overhead Projector & 16 & 16.00 & 84 & 84.00 & Not available \\
\hline 7. & Multimedia projector & 8 & 8.00 & 92 & 92.00 & Not available \\
\hline 8. & Video tape recorder & 8 & 8.00 & 92 & 92.00 & Not available \\
\hline 9. & Charts & 81 & 81.00 & 19 & 19.00 & Available \\
\hline 10. & Globes & 66 & 66.00 & 34 & 34.00 & Available \\
\hline 11. & Computers & 67 & 67.00 & 33 & 33.00 & Available \\
\hline 12. & Television & 29 & 29.00 & 71 & 71.00 & Not available \\
\hline 13. & CD Player & 30 & 30.00 & 70 & 70.00 & Not available \\
\hline 14. & Microphone & 44 & 44.00 & 66 & 66.00 & Not available \\
\hline 15. & Measuring Cylinder & 84 & 84.00 & 16 & 16.00 & Available \\
\hline 16. & Chemical balance & 93 & 93.00 & 7 & 7.00 & Available \\
\hline 17. & Hand lenses & 93 & 93.00 & 7 & 7.00 & Available \\
\hline 18. & Microscope & 20 & 20.00 & 80 & 80.00 & Not available \\
\hline 19. & Beakers & 93 & 93.00 & 7 & 7.00 & Available \\
\hline 20. & Skeleton & 84 & 84.00 & 16 & 16.00 & Available \\
\hline 21. & Pipette & 72 & 72.00 & 28 & 28.00 & Available \\
\hline 22. & Calorimeter & 62 & 62.00 & 38 & 38.00 & Available \\
\hline 23. & Periodic table & 86 & 86.00 & 14 & 14.00 & Available \\
\hline 24. & Thermometer & 81 & 81.00 & 19 & 19.00 & Available \\
\hline 25. & Watch glass & 76 & 76.00 & 24 & 24.00 & Available \\
\hline 26. & Batteries & 74 & 74.00 & 26 & 26.00 & Available \\
\hline 27 & Meter rule & 86 & 86.00 & 14 & 14.00 & Available \\
\hline 28. & Rectangular prism & 83 & 83.00 & 17 & 17.00 & Available \\
\hline 29. & Tuning fork & 83 & 83.00 & 17 & 17.00 & Available \\
\hline 30. & Ray boxes & 80 & 80.00 & 20 & 20.00 & Available \\
\hline 31. & Pendulum bobs & 88 & 88.00 & 12 & 12.00 & Available \\
\hline 32. & Lenses & 93 & 93.00 & 7 & 7.00 & Available \\
\hline 33 & Spring balance & 79 & 79.00 & 21 & 21.00 & Available \\
\hline 34. & Trolley & 66 & 66.00 & 34 & 34.00 & Available \\
\hline 35. & Vanier calipers & 81 & 81.00 & 19 & 19.00 & Available \\
\hline
\end{tabular}


The answer to the research question one is derived from the data displayed in table 2 , where out of a total of 35 instructional materials listed that are used in public schools, a Cumulative Frequency of instructional materials available shows that $2258(64.51 \%)$ of instructional materials were available, while $1242(35.49 \%)$ of instructional materials were not available. Therefore with regards to research question one instructional materials are available for teaching in secondary schools in Delta State.

\section{Research Question 2}

Are instructional resources adequate for teaching in secondary schools in Delta State?

Table 3: Adequacy of Instructional Resource materials for teaching in secondary schools in Delta State

\begin{tabular}{|c|c|c|c|c|c|c|}
\hline $\mathbf{S} / \mathbf{N}$ & Material Resources & $\begin{array}{c}\text { Yes } \\
\text { (Adequate) }\end{array}$ & $\%$ & $\begin{array}{c}\text { No } \\
\text { (Not Adequate) }\end{array}$ & $\%$ & Remarks \\
\hline 1. & Chalkboard & 75 & $75 . .00$ & 25 & 25.00 & Adequate \\
\hline 2. & Marker Board & 34 & 34.00 & 66 & 66.00 & Not adequate \\
\hline 3. & Textbooks & 56 & 56.00 & 44 & 44.00 & Adequate \\
\hline 4. & Realia & 26 & 26.00 & 74 & 74.00 & Not adequate \\
\hline 5. & Tape recorder & 15 & 15.00 & 85 & 85.00 & Not adequate \\
\hline 6. & Overhead Projector & 12 & 12.00 & 88 & 88.00 & Not adequate \\
\hline 7. & Multimedia projector & 25 & 25.00 & 75 & 75.00 & Not adequate \\
\hline 8. & Video tape recorder & 18 & 18.00 & 82 & 82.00 & Not adequate \\
\hline 9. & Charts & 46 & 46.00 & 54 & 54.00 & Not adequate \\
\hline 10. & Globes & 24 & 24.00 & 76 & 76.00 & Not adequate \\
\hline 11. & Computers & 28 & 28.00 & 72 & 72.00 & Not adequate \\
\hline 12. & Television & 26 & 26.00 & 74 & 74.00 & Not adequate \\
\hline 13. & CD Player & 20 & 20.00 & 80 & 80.00 & Not adequate \\
\hline 14. & Microphone & 34 & 34.00 & 66 & 66.00 & Not adequate \\
\hline 15. & Measuring Cylinder & 43 & 43.00 & 57 & 57.00 & Not adequate \\
\hline 16. & Chemical balance & 43 & 43.00 & 57 & 57.00 & Not adequate \\
\hline 17. & Hand lenses & 49 & 49.00 & 51 & 51.00 & Not adequate \\
\hline 18. & Microscope & 37 & 37.00 & 63 & 63.00 & Not adequate \\
\hline 19. & Beakers & 43 & 43.00 & 57 & 57.00 & Not adequate \\
\hline 20. & Skeleton & 33 & 33.00 & 67 & 6700 & Not adequate \\
\hline 21. & Pipette & 54 & 54.00 & 46 & 46.00 & Adequate \\
\hline 22. & Calorimeter & 35 & 35.00 & 65 & 65.00 & Not adequate \\
\hline 23. & Periodic table & 53 & 53.00 & 47 & 47.00 & Adequate \\
\hline 24. & Thermometer & 38 & 38.00 & 62 & 62.00 & Not adequate \\
\hline 25. & Watch glass & 51 & 51.00 & 49 & 49.00 & Adequate \\
\hline 26. & Batteries & 42 & 42.00 & 58 & 58.00 & Not adequate \\
\hline 27 & Meter rule & 61 & 61.00 & 39 & 39.00 & Adequate \\
\hline 28. & Rectangular prism & 52 & 52.00 & 48 & 48.00 & Adequate \\
\hline 29. & Tuning fork & 34 & 34.00 & 66 & 66.00 & Not adequate \\
\hline 30. & Ray boxes & 51 & 51.00 & 49 & 49.00 & Adequate \\
\hline 31. & Pendulum bobs & 54 & 54.00 & 46 & 46.00 & Adequate \\
\hline 32. & Lenses & 58 & 58.00 & 42 & 42.00 & Adequate \\
\hline 33 & Spring balance & 43 & 43.00 & 57 & 57.00 & Not adequate \\
\hline 34. & Trolley & 36 & 36.00 & 64 & 64.00 & Not adequate \\
\hline 35. & Vanier calipers & 40 & 40.00 & 60 & 60.00 & Not adequate \\
\hline
\end{tabular}

The answer to research question two was obtained from the data displayed in table 3 , where out of a total of 35 instructional materials listed that are used in rural and urban public schools, a Cumulative Frequency on the adequacy of instructional materials shows that $1423(40.66 \%)$ of instructional materials were Not- Adequate, therefore depicting a wide range of inadequacy of 2077 (59.34\%) indicating that, instructional materials are NotAdequate for teaching in secondary schools in Delta State.

\section{Research Question 3}

What is the level of utilization of instructional resources for teaching in secondary schools in Delta State?

Table 4: Statistics of the responses on the level of Utilization of Instructional Resources in Secondary 
Schools

\begin{tabular}{|c|c|c|c|c|c|c|c|}
\hline Variable item & $\mathrm{N}$ & $\begin{array}{c}\text { Fully } \\
\text { Utilized } \\
(\mathrm{FU})\end{array}$ & $\begin{array}{l}\text { Moderately } \\
\text { Utilized } \\
\text { (MU) }\end{array}$ & $\begin{array}{l}\text { Under } \\
\text { Utilized } \\
\text { (UU) }\end{array}$ & $\begin{array}{c}\text { Less } \\
\text { Utilized } \\
\text { (LU) }\end{array}$ & Mean & $\begin{array}{c}\text { Std. } \\
\text { Deviation }\end{array}$ \\
\hline Chalkboard & 100 & 72 & 22 & 6 & 0 & 3.660 & 0.590 \\
\hline Marker Board & 100 & 62 & 14 & 5 & 19 & 3.190 & 1.187 \\
\hline Textbooks & 100 & 66 & 7 & 0 & 7 & 3.720 & 0.792 \\
\hline Realia & 100 & 21 & 36 & 4 & 39 & 2.390 & 1.205 \\
\hline Tape Recorder & 100 & 9 & 2 & 31 & 58 & 1.620 & 0.908 \\
\hline OverHead Projector & 100 & 0 & 18 & 23 & 59 & 1.590 & 0.780 \\
\hline Multimedia Projector & 100 & 0 & 13 & 28 & 59 & 1.540 & 0.717 \\
\hline Video Tape Recorder & 100 & 14 & 0 & 24 & 62 & 1.660 & 1.037 \\
\hline Charts & 100 & 51 & 35 & 3 & 11 & 3.260 & 0.960 \\
\hline Globes & 100 & 29 & 40 & 14 & 17 & 2.810 & 1.042 \\
\hline Computers & 100 & 46 & 9 & 24 & 21 & 2.800 & 1.231 \\
\hline Television & 100 & 0 & 0 & 21 & 79 & 1.210 & 0.409 \\
\hline CD Player & 100 & 0 & 3 & 31 & 66 & 1.370 & 0.544 \\
\hline Microphone & 100 & 24 & 15 & 21 & 40 & 2.230 & 1.213 \\
\hline Measuring Cylinder & 100 & 56 & 24 & 6 & 14 & 3.220 & 1.069 \\
\hline Chemical Balance & 100 & 50 & 30 & 3 & 17 & 3.130 & 1.098 \\
\hline Hand Lenses & 100 & 56 & 21 & 6 & 17 & 3.160 & 1.135 \\
\hline Microscope & 100 & 20 & 55 & 5 & 20 & 2.750 & 0.999 \\
\hline Beakers & 100 & 54 & 23 & 16 & 7 & 3.240 & 0.965 \\
\hline Skeleton & 100 & 53 & 25 & 6 & 16 & 3.150 & 1.104 \\
\hline Pipette & 100 & 70 & 6 & 10 & 14 & 3.320 & 1.127 \\
\hline Calorimeter & 100 & 52 & 9 & 22 & 17 & 2.960 & 1.197 \\
\hline Periodic Tables & 100 & 68 & 11 & 11 & 10 & 3.370 & 1.031 \\
\hline Thermometer & 100 & 54 & 7 & 26 & 13 & 3.020 & 1.155 \\
\hline Watch Glass & 100 & 42 & 12 & 14 & 32 & 2.640 & 1.314 \\
\hline Batteries & 100 & 57 & 17 & 2 & 24 & 3.070 & 1.249 \\
\hline Meter Rule & 100 & 74 & 9 & 0 & 17 & 3.400 & 1.128 \\
\hline Rectangular Prism & 100 & 55 & 22 & 9 & 14 & 3.180 & 1.086 \\
\hline Turning Fork & 100 & 36 & 24 & 5 & 35 & 2.610 & 1.294 \\
\hline Ray Boxes & 100 & 54 & 19 & 3 & 24 & 3.030 & 1.243 \\
\hline Pendulum Bobs & 100 & 61 & 6 & 3 & 30 & 2.980 & 1.363 \\
\hline Lenses & 100 & 58 & 19 & 6 & 17 & 3.180 & 1.140 \\
\hline Spring Balance & 100 & 55 & 21 & 13 & 11 & 3.200 & 1.044 \\
\hline Trolley & 100 & 35 & 8 & 16 & 41 & 2.370 & 1.331 \\
\hline Vernier Calipers & 100 & 49 & 13 & 5 & 33 & 2.780 & 1.353 \\
\hline Total Average & & & & & & 2.766 & 0.672 \\
\hline
\end{tabular}

With regards to the Utilization of Instructional Resource in Secondary Schools in Delta state. Table 4 shows that twenty six (26) variable items out of the thirty five (35) items were considered fully utilized as a result of their individual mean score higher than the average mean mark of 2.50, while the remaining nine (9) variable items were considered less utilized because their individual mean score is lower than the average mean mark of 2.50 .

The answer to research question three is derived from the mean score of variable items in table 4 , where variable items whose mean score are above the standard 2.50 mean mark are considered as fully utilized (using the topmost positive level), while variable items with mean score less than the average 2.50 mean are considered underutilized (using the topmost negative level). A frequency count of variable items above the 2.50 mean marks shows that 26 items score above the 2.50 mean mark while 9 items scored below the 2.50 mean mark, thereby indicating with regards to research question three that instructional resources are fully utilized for teaching in secondary schools on Delta State.

\section{Discussion of Results}

The result of the study revealed that the general resources for teaching such as chalk boards, marker boards as well as textbooks were available in most schools. However, most twenty first century technological teaching materials such as tape recorders, overhead projectors, multimedia projectors, computers, microphones are not available in most of the schools sampled.

Generally, instructional resources are available for teaching in public secondary schools in Delta State. The 
result of the study is in agreement with Ngure (2012) and Olagunju and Abiona (2012) studies that instructional resources for teaching are available in schools. However, the result of the study is contrary to Olelekwe; Nzeadibe and Nzeadibe (2014) study that instructional resources for meaningful teaching and learning experience are not available.

The result of the study reveals that the resources for teaching such as chalk boards, marker boards as well as textbooks are inadequate in most schools. The 21 st century technological teaching materials such as tape recorders, overhead projectors, multimedia projectors, computers, microphones are not available in most of the schools sampled and invariably not adequate.

The result of the finding is in agreement with Owoeye and Yara (2011), Ugwanyi (2013), Uwamieye (2016), Yusuf (2014), Likoko; Mutsotso and Nasongo (2013) that material resources for teaching as required are not adequate in schools. This is contrary to the report of Ngure (2012) and Alonu (2014) that material resources for classroom instruction are adequate.

The result of the analysis revealed that material resources in public secondary schools in Delta state are not adequate for utilization. Specifically, materials showing fully utilized in utilization may not be unconnected with the fact that some of the materials are few where they are available for practical lessons and examinations, if this is the case quality teaching and learning may not be achieved until more supplies are made.. The result of the study is contrary to Ede and Olaitan (2010), Ogwari (2013) as well as Okoro (2017) that materials resources are fairly utilized in secondary schools.

\section{Findings}

Based on results from data analysis, the following findings were made:

1. Instructional resources for teaching are available in $64.16 \%$ of secondary schools in Delta State.

2. Instructional resources are $40.66 \%$ adequate in secondary schools in the state.

3. Instructional resources for teaching students in secondary schools in the state are fully utilized.

\section{Recommendations}

The findings above necessitated the following recommendations;

1. The governments should strive to ensure adequacy of instructional resources in the schools by making available more resources to enhance sufficiency.

2. The physical resources adequacy should be improved upon to make the classrooms, staff rooms and general school environment conducive for learning.

3. Principals and their vice should be adequately trained on effective utilization of limited instructional resources to enhance the attainment of school goals and objectives.

4. Administrators should bear in mind the need to make annual supplies of the materials that require replenishing and replacement of non-serviceable instructional resources for continuous teaching and learning.

\section{Conclusion}

Based on the findings of the study, it was concluded that instructional resources are available yet inadequate to teach students in the secondary schools in Delta State. The extent of adequacy of the instructional resources has affected their utilization such that inadequate resources has given room for over stretched materials while the inadequate resources culminates into situations of overcrowded classrooms, laboratories and workshops that has minimal quantity of materials and other consumables for effective teaching and learning.

\section{References}

Adeoye, O. M. \& Popoola, S.O. (2011). Teaching effectiveness, availability and use of library information resources among teaching of nursing in Osun and Oyo State, Chyara. Educotec 1(3), 102-108

Adeyanju, F. \& Oyetubo, O. (2012). Infrastructural resources provision and utilization for the universal basic education (UBE) scheme in Lagos State in R. O. Olubor, S.O. Okotete (Eds) Resource management in education and nation's development. Benin City: Institute of Education.

Akinsanya, O. (2010). Differential distribution and utilization of human and material resources on students academic performance in secondary schools in Ogun State. African Journal for the Study of Educational Issues 3(4).

Asiyai, R. I. (2012). Assessing school facilitates in public secondary schools in Delta State Nigeria. African Research Review 6(2) 192-205.

Dawari, I. H (2012) Educational resources provision and quality education in secondary schools in Rivers State. African Journal of Educational Research and Development AJERD, 5(1) ,103-113.

Durosaro, D. O. (2010). Resources allocation and utilization for university education in Nigeria. trend and issues. In O. A Fagbamiye and D.O Durosaro (Eds). Education and productivity in Nigeria. Ilorin: NAEAP 
Publishers.

Ebohimen, P.(2012). Educational system strategy for national development: Balanced scorecard approach. In R.O Olubor, S.O. Okotete \& F. Adeyanju (Eds.) Resources management in education and national development. Benin City: Institute of Education University of Benin.

Edokpolo, A. (2011, December 20). The Challenges of Nigerian education system and the way forward. Benin City: The Nigerian Voice.

Ekwutosi, O.B. \& Ogbonnaya, O.O. (2015). Adequacy of material resources required for

implementation of upper basic education business education curriculum in Ebonyi State Nigeria. African Journal of Teacher Education, 4(1),18-26.

Federal Republic of Nigeria (2014). National policy on education ( $\sigma^{\text {th }}$ edition). Lagos: NERDC Press.

Igbinoghene, V. \& Nosahaba, M.A.E. (2014). Prudential measures for managing existing educational resources in Nigerian Educaiton. An Introduction Journal of Contemporary Issues in Education, 2 (1), 60-71.

Ogbuka, L.A.R .(2015). A comparative analysis of the need and availability of science teachers in senior secondary schools in Delta and Imo States.(Unpublished doctoral dissertation) Delta State University, Abraka.

Ogundele M. O. (2007). Funding, teacher job satisfaction and students academic performance in Kwara private secondary schools.( Unpublished doctoral dissertation) University of Ilorin.

Okai, O. N. \& Ndukuru,Y. A. (2014). Resource Management: A Tool for Higher Institutions Goal Attainment. The Case of River State. African Journal of Higher Education Studies and Development 2(1).

Olelewe, C. J., Nzeadibe, C.A. \& Nzeadibe, C.T.(2014). Availability and utilization of educational resources in selected rural communities of Enugu state: Implications for achieving universal primary education of the millennium development goals (MDGs) in Nigeria. Educational Research International, 3(1), 15-24

Oluwuo, S.O \& Ekoro, L. (2014). Assessment of physical resource for the implementation of Universal Basic Education (UBE) in primary schools in Rivers State. African Journal of Educational Research and Development, 7(1), 12-20.

Owoeye, P. \& Yara, M. (2010). School facilities and academic achievement of secondary school Agricultural Science in Ekiti State Nigeria. Asian Science Journal, 7(7). 142-149.

Ugwanyi, J.I. (2013). Availability, adequacy and utilization of Physical Education teaching resources in secondary schools in Enugu State.(Unpublished master's thesis) University of Nigeria Nsukka.

Umezulike, L. (2015, May 7). The Parlous state of education. The Nation. 